\title{
Concentrations and relative compositions of metallic elements differ between predatory squid and filter-feeding sardine from the Indian and South Atlantic oceans
}

Ryan Uren, Carl van der Lingen, Henrik Kylin and Hindrik Bouwman

The self-archived postprint version of this journal article is available at Linköping University Institutional Repository (DiVA):

http://urn.kb.se/resolve?urn=urn:nbn:se:liu:diva-1635.58

N.B.: When citing this work, cite the original publication.

Uren, R., van der Lingen, C., Kylin, H., Bouwman, H., (2020), Concentrations and relative compositions of metallic elements differ between predatory squid and filter-feeding sardine from the Indian and South Atlantic oceans, Regional Studies in Marine Science, 35, 101137.

https://doi.org/10.1016/j.rsma.2020.101137

Original publication available at:

https://doi.org/10.1016/j.rsma.2020.101137

Copyright: Koeltz Scientific Books

Publisher URL Missing 
Concentrations and relative compositions of metallic elements differ between predatory squid and filter-feeding sardine from the Indian and South Atlantic oceans

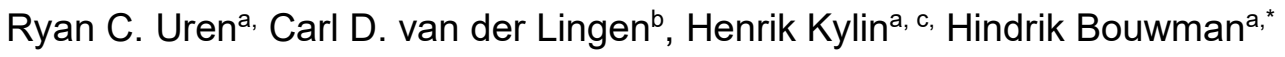

${ }^{a}$ Research Unit: Environmental Sciences and Management, North-West University, Potchefstroom, South Africa

bBranch: Fisheries Management, Department of Environment, Forestry and Fisheries, Cape Town; and Marine Research Institute and Department of Biological Sciences, University of Cape Town, Cape Town, South Africa

'Department of Thematic Studies - Environmental Change, Linköping University, Linköping, Sweden

${ }^{*}$ Corresponding author at:

Research Unit for Environmental Sciences and Management North-West University

P. Bag X6001

Potchefstroom 2520

South Africa

Tel: +27716888241

Fax: +27 182992503

henk.bouwman@nwu.ac.za

Highlights

- First assessment of metal concentrations in sardine and squid from South Africa

- Concentrations differed between organisms from the South Atlantic and Indian Oceans

- A number of metals occurred at higher concentrations in the predatory squid

- 'Fingerprint' analyses indicate possible stock discrimination for sardine and squid

- No mean concentrations exceeded recommended human intake limits

Key words: South Atlantic Ocean; Indian Ocean; muscle tissue; cadmium; mercury; lead. 


\begin{abstract}
Although metallic elements occur naturally, they can occur or accumulate in organisms at levels toxic to the organism and/or their consumers. Concentrations of twenty-nine metallic elements in muscle tissue from sardine Sardinops sagax and chokka squid Loligo reynaudii from South Atlantic and Indian Ocean waters off South Africa were established, for the first time, using inductively-coupled plasma mass spectrometry. Chokka showed significantly higher $(p<0.05)$ concentrations of B, Cr, Zn, As, Se, Rb, Sr, Cd, and TI and significantly lower concentrations of $\mathrm{V}, \mathrm{Mn}, \mathrm{Ti}$, and $\mathrm{Mo}$ compared to sardine. There were also significant differences in some metallic elements between the two oceans. Multivariate analyses indicated possible population structure of both species, suggesting that these analyses may be useful as a stock discrimination tool. Only two sardine samples contained quantifiable $\mathrm{Hg}$. Based on South African estimated daily intake, total hazard quotient, and European Union limits for $\mathrm{Hg}, \mathrm{Cd}$, and $\mathrm{Pb}$, we consider tissues from sardine and chokka in South African waters to be safe for human consumption.
\end{abstract}




\section{Introduction}

The aquatic ecosystem is both a receiver and a reservoir for pollutants such as metals and persistent organic pollutants (Bouwman et al., 2015; Newman and Watling, 2007; Smita Achary et al., 2017). The uptake of pollutants by aquatic biota occurs through a dissolved state in water flowing over the body and gills, the organism's diet, or combinations thereof (Fernandez et al., 2014). Metallic elements occur in the environment naturally, or elevated above natural background levels due to pollution from mining, industry, and agriculture (du Preez et al., 2018; Greenfield et al., 2011; Nel et al., 2015; O'Donoghue and Marshall, 2003; Wepener and Degger, 2012). Fish and cephalopods are good bio-indicators of metallic elements because they occupy many trophic levels, can accumulate pollutants over long lifespans, and in some cases, exhibit severe effects (Jiang et al., 2018; Mziray and Kimirei, 2016; Viera et al., 2011). Organisms at higher trophic levels also tend to accumulate higher concentrations of pollutants, potentially making them more susceptible to the effects of excess pollutants such as metals (Fernandez et al., 2014), and passing them on to yet higher trophic levels.

South Africa is bordered by two oceans; the Indian Ocean on the east and south coasts, and the South Atlantic Ocean on the west coast, with these two oceans adjoining in the region of Cape Agulhas $\left(20^{\circ} \mathrm{E}\right.$; Hutchings et al., 2009, Fig 1.). The upwelling of cold, nutrient-rich water onto the west coast shelf in the austral spring and summer and due to south easterly winds makes these waters in the South Atlantic Ocean highly productive. The south coast is impacted by the warm Agulhas Current at the shelf edge, shows shelf-edge and coastal upwelling, and is characterised by both easterly and westerly winds. Shelf waters are stratified in summer and mixed in winter. Circulation patterns are complex but create a clockwise eddy that circulates around a sub-surface cool ridge and acts as a retention area for phytoplankton and zooplankton (Hutchings et al., 2009), and likely also nutrients and metals.

The sardine Sardinops sagax is an economically and ecologically important fish (Beckley and van der Lingen, 1999) for the South African small pelagic fishery. Annual catches of sardines since 1990 ranged between 51,000 and 374,000 metric tons, and it is mainly canned for human consumption, pet food, and bait (DAFF, 2016). Sardines are prey to many predators such as Cape fur seals Arctocephalus pusillus, sea birds, and squids (Bouwman et al., 2015; Connan et al., 2017; Huisamen et al., 2012). Chokka or the Cape Hope squid Loligo reynaudii also supports a commercial fishery for human consumption (mostly export) and bait. Chokka are caught primarily with jigging from deck boats, and as by-catch in demersal trawls. Annual catches fluctuated between 2,700 and 13,300 metric tons between 2003 and 2015 (DAFF, 2016).

The South African sardine is primarily an indiscriminate filter feeder, feeding mostly on phytoplankton, zooplankton, and fish eggs (van der Lingen, 2002), making the sardine a primary and secondary consumer. Chokka are opportunistic predators during all life stages, with juveniles favouring crustaceans and adults feeding mostly on small pelagic fish and other cephalopods (Augustyn et al., 1994; Lipinski, 1992; Sauer and Lipinski, 1991).

Because chokka feed on small pelagic fish as part of their diet, they occupy a higher trophic level than do sardines, as shown by stable isotope analyses; chokka had higher nitrogen stable isotope ratios $\left(\delta^{15} \mathrm{~N}\right.$; an index of trophic level) (mean 13.8, trophic level 4.08$)$ than did sardines (mean 11.1, trophic level 3.0; van der Lingen and Miller, 2011). While sardines would be exposed to and potentially accumulate metals via uptake from both water and ingestion of filtered food particles, chokka squid would be exposed to metals in water and 
metals accumulated by their prey (likely including sardines), potentially resulting in higher body burdens. However, physiologically important elements may be regulated to stay within physiological limits, resulting in narrower concentration variations than in elements that are not so regulated (Emsley, 2003).

The aim of this study was to establish metallic element concentrations and patterns in sardine and chokka muscle tissues from the South Atlantic and Indian Ocean coasts of South Africa. We compare the concentrations within and between species from the same ocean, and compare within species between the two oceans. We also assess levels of three major toxic metals (cadmium $(\mathrm{Cd})$, lead $(\mathrm{Pb})$ and mercury $(\mathrm{Hg})$ ) for human consumer safety.

\section{Methods and Materials}

\subsection{Sardine and chokka collection sites}

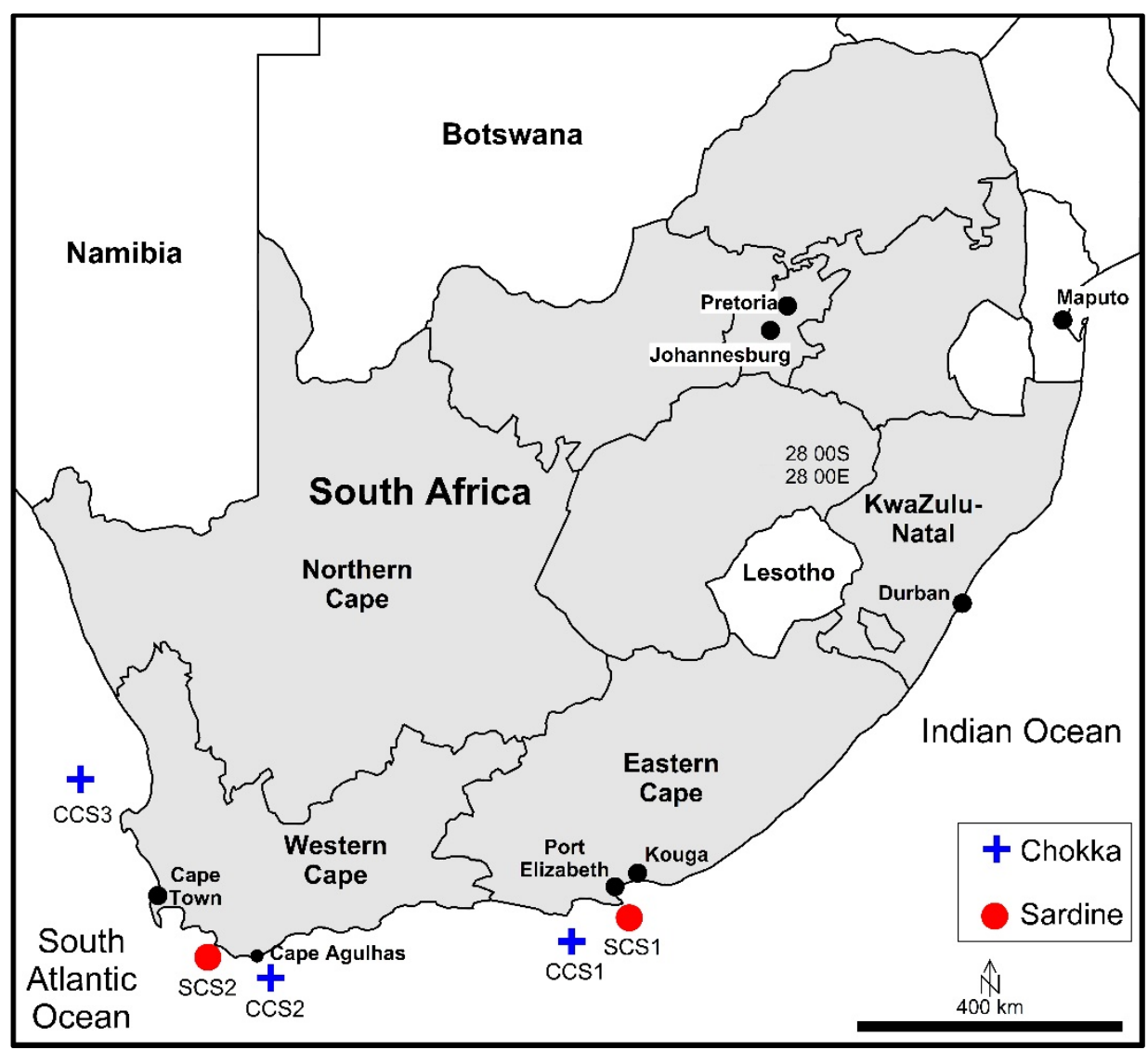

Fig. 1. Map of sardine and chokka sample collection sites.

Sardine and chokka samples were received from the South African Department of Agriculture, Forestry, and Fisheries (DAFF). The sardine samples (SCS1 and SCS2; bottom depths $39 \mathrm{~m}$ and $68 \mathrm{~m}$, respectively) were sourced from commercial catches (Figure 1) in March 2017. Sardine standard length ranged from 150-195 mm, while mass ranged from 51$120 \mathrm{~g}$. One of the chokka samples (CCS1, bottom depth $162 \mathrm{~m}$ ) was sourced from a commercial catch made in the Indian Ocean in November 2017. The other two chokka samples (CCS2 and CCS3, bottom depths $192 \mathrm{~m}$ and $145 \mathrm{~m}$, respectively) were sourced from demersal trawls conducted during a research survey off the west coast in February 2017. Chokka total length ranged from $160-320 \mathrm{~mm}$, and mass ranged from $45-504 \mathrm{~g}$. 
Fish and chokka were chilled on ice after capture. Whole samples were selected randomly for analyses, and then frozen. The sardine and chokka samples were couriered frozen from Cape Town and Port Elizabeth to the laboratory at the North-West University (NWU) in Potchefstroom, South Africa, where they were received frozen and stored in $-20^{\circ} \mathrm{C}$ freezers pending analysis.

\subsection{Dissection of sardine and chokka}

We thawed sardine and chokka samples at room temperature until they were in workable condition (still firm). Sardine muscle tissue and chokka mantle (without skin) samples were taken and weighed to obtain wet mass (approximately $10 \mathrm{~g}$ ) from both dorso-lateral sides of the fish and squid, and transferred to $50 \mathrm{ml}$ high-density polypropylene centrifuge tubes. The weighed samples were first frozen and then freeze-dried for three days at $8 \mathrm{kPa}$ and $-50{ }^{\circ} \mathrm{C}$. The freeze-dried samples were then weighed to obtain dry mass (approximately $2 \mathrm{~g}$ ).

\subsection{Analyses of sardine and chokka}

Freeze-dried samples were analysed by Eco-Analytica at the North-West University (NWU). Accurately weighed tissue samples were dissolved in concentrated nitric acid, and microwave-digested with an Ethos UP microwave unit, as per the United States Environmental Protection Agency method 3051A. The sample and acid were placed in a fluorocarbon polymer vessel, sealed, and heat-digested in the microwave unit for 35 minutes.

A standard reference material (SRM) (ERM-CE278K - marine mussel tissue) was used as quality control (QC) with the same digestion protocol. We analysed the microwavedigested solutions using an Agilent $7500 \mathrm{ce}$, inductively-coupled-plasma mass-spectrometer (ICP-MS), optimised with an aqueous solution containing cerium (Ce), lithium (Li), ytterbium $(\mathrm{Y})$, and thallium $(\mathrm{TI})(1 \mu \mathrm{g} / \mathrm{L})$ to reduce interference $(\leq 1.5 \%)$. Forward power was $1550 \mathrm{~W}$, plasma gas flow was set at $15 \mathrm{l} / \mathrm{min}$, the nebuliser gas flow was $1.2 \mathrm{l} / \mathrm{min}$, and the sampling depth in the container was at $8 \mathrm{~mm}$. We quantified twenty-nine elements.

For external calibration, we used ULTRASPEC-certified mixed multi-element standard solutions (De Bruyn Spectroscopic Solutions). Full calibration sets and QC-check standards were run. The QC check standard was a calibration standard of midrange concentration. Detection limits for each element analysed are indicated in table S1. Data are expressed as $\mathrm{mg} / \mathrm{kg}$ dry mass $(\mathrm{dm})$. Wet-mass based concentrations were calculated $(\mathrm{mg} / \mathrm{kg} \mathrm{wm}$, see section 2.2) for comparisons with intake limits.

\subsection{Statistical analysis}

We tested data for normality using the Shapiro-Wilks normality test (GraphPad Prism 7.04; www.graphpad.com). Data that were not normally distributed were log-transformed. We used two-tailed t-tests to compare mean metal concentrations between the same species from different oceans, and between species from the same ocean. We used Kruskal-Wallis (unpaired, non-parametric, one-way ANOVA) to compare concentrations between the three chokka collection sites, using Dunn's test to correct for multiple comparisons.

For multivariate analyses, we used nonmetric-multidimensional-scaling (NMS) to ordinate the metal concentrations for species and collection sites (MjM Software PC-ORD version 7.03; www.pcord.com). The data were relativized per element to obtain proportional 
elemental compositions per sample (or 'fingerprints'). Four axes were allowed. We selected Gower-ignore- 0 as the distance measure. The maximum number of iterations allowed was 200. Fifty runs of real data were used with random starting configurations. Monte Carlo tests were then performed with randomised data, also using 50 runs. We used convex hulls to visualise relative elemental compositions of species and collection sites.

\section{Results}

\subsection{Concentrations}

We analysed 18 sardines and 15 chokka from the South Atlantic, and 12 sardines and ten chokka from the Indian Ocean. Recoveries of certified elements were within $20 \%$ of SRM certified values. Beryllium, $\mathrm{Ni}, \mathrm{Ag}, \mathrm{Bi}$ and $\mathrm{Au}$ were below detection limits in sardine muscle. Beryllium, $\mathrm{Ni}, \mathrm{Au}$ and $\mathrm{Bi}$ were below detection limits in chokka muscle. Summary results of the 14 elements that had significantly different concentrations in the same species between oceans are presented in Table 1. Summarised data for all elements analysed per species and sample site are presented in Table S1.

\subsection{Concentration differences between sardines from different oceans}

Significant differences (un-paired, two-way t-tests; $p<0.05$ ) were found between sardines from the two different oceans for mean concentrations of B, V, Cr, As, Se, Rb, Mo, Cd, and TI (Table 1; Figures 2 and 3). Boron, V, Cr, Se, Mo, Cd, As, and TI had significantly ( $p<$ 0.05 ) higher mean concentrations in sardines from the South Atlantic Ocean with only Rb showing significantly higher concentrations in fish from the Indian Ocean. Titanium, Mn, Zn, Co, and Sr mean concentrations were not significantly different between sardines from the two oceans (Figures 2 and 3).

\subsection{Concentration differences between chokka from different oceans}

We found significant differences (un-paired, two-way t-tests; $p<0.05$ ) in mean concentrations between chokka from the Indian and South Atlantic oceans for Ti, V, Mn, Rb, and $\mathrm{Sr}$. Chokka from the Indian Ocean had significantly higher mean concentrations of $\mathrm{V}$, $\mathrm{Rb}, \mathrm{Mn}$, and Sr (Figures 2 and 3). Boron, Cr, Co, Zn, As, Se, Mo, Cd, and TI showed no mean concentration differences between samples from the South Atlantic and Indian oceans.

\subsection{Concentration differences between sardines and chokka per ocean}

In both oceans, sardines had significantly (un-paired, two-way t-tests; $p<0.05$ ) higher mean concentrations compared with chokka for $\mathrm{V}$, Co, and Mo, and for $\mathrm{Mn}$ for the Atlantic Ocean only. Chokka had significantly higher (un-paired, two-way t-tests; $p<0.05$ ) concentrations than sardines for $\mathrm{B}, \mathrm{Ti}, \mathrm{Cr}, \mathrm{Zn}, \mathrm{As}, \mathrm{Se}, \mathrm{Rb}, \mathrm{Sr}, \mathrm{Cd}$, and $\mathrm{TI}$ (Figures 2 and 3) in both oceans.

\subsection{Multivariate analyses of relative elemental compositions of sardine and chokka per collection site}

Two dimensions were needed to ordinate the relative elemental compositions in sardine muscle, with a final stress of 11.7 , and a final instability of 0.00017 , reached after 30 iterations (Figure 4). According to Clarke's rule of thumb (McCune and Grace, 2002), a final 
stress between 10 and 20 presents a usable picture for interpretation. Sardine sample site 1 (SCS1, Indian Ocean) had a convex hull that did not overlap with SCS2 from the South Atlantic Ocean. SCS1 was characterised by higher relative proportions of $\mathrm{Th}, \mathrm{Sb}, \mathrm{Pt}$, and $\mathrm{Pb}$, while SCS2 was characterised by higher relative proportions of $\mathrm{B}, \mathrm{TI}, \mathrm{Mo}, \mathrm{Cd}$, and $\mathrm{V}$.

Three dimensions were needed to ordinate the relative elemental compositions in chokka muscle tissue, of which we show only two (Figure 5). The third dimension explained $21.8 \%$ of the variability. The final stress was 9.89 , and the final instability was $<0.0001$, reached after 54 iterations. According to Clarke's rule of thumb (McCune and Grace, 2002), a final stress between 5 and 10 presents a good ordination with little risk of deriving false inferences. The chokka collection sites had distinctly different profiles, with especially CCS1 characterised by higher relative proportions of $\mathrm{Mn}, \mathrm{U}$, and $\mathrm{V}$.

Table 1: Concentrations $(\mathrm{mg} / \mathrm{kg} \mathrm{dm})$ of metallic elements in muscle tissue that had significantly different $(p<0.05)$ concentrations according to species and catch site.

\begin{tabular}{|c|c|c|c|c|c|c|c|}
\hline \multirow{2}{*}{ Element } & \multirow{2}{*}{ Organism } & \multicolumn{3}{|c|}{ Indian Ocean } & \multicolumn{3}{|c|}{ Atlantic Ocean } \\
\hline & & $\mathrm{N}$ & Mean & SD & $\mathrm{N}$ & Mean & SD \\
\hline$B$ & Sardine & 8 & 0.73 & 0.82 & 18 & 1.5 & 0.67 \\
\hline$B$ & Chokka & 10 & 5.2 & 2.8 & 15 & 5.5 & 1.1 \\
\hline $\mathrm{Ti}$ & Sardine & 12 & 18 & 2.7 & 18 & 17 & 2.3 \\
\hline $\mathrm{Ti}$ & Chokka & 10 & 21 & 1.2 & 15 & 23 & 2.1 \\
\hline V & Sardine & 12 & 0.29 & 0.17 & 18 & 2.0 & 0.96 \\
\hline V & Chokka & 10 & 0.12 & 0.078 & 15 & 0.039 & 0.028 \\
\hline $\mathrm{Cr}$ & Sardine & 12 & 0.61 & 0.064 & 18 & 0.66 & 0.069 \\
\hline $\mathrm{Cr}$ & Chokka & 10 & 1.6 & 0.21 & 15 & 1.6 & 0.18 \\
\hline $\mathrm{Mn}$ & Sardine & 12 & 2.2 & 1.0 & 18 & 2.3 & 0.93 \\
\hline $\mathrm{Mn}$ & Chokka & 10 & 2.6 & 1.3 & 15 & 1.1 & 0.16 \\
\hline Co & Sardine & 12 & 0.078 & 0.032 & 18 & 0.083 & 0.036 \\
\hline Co & Chokka & 10 & 0.027 & 0.0064 & 15 & 0.022 & 0.011 \\
\hline $\mathrm{Zn}$ & Sardine & 12 & 27 & 13 & 18 & 21 & 4.0 \\
\hline $\mathrm{Zn}$ & Chokka & 10 & 46 & 3.1 & 15 & 47 & 2.4 \\
\hline As & Sardine & 12 & 2.7 & 0.60 & 18 & 4.1 & 0.95 \\
\hline As & Chokka & 10 & 17 & 6.1 & 15 & 17 & 2.7 \\
\hline $\mathrm{Se}$ & Sardine & 12 & 1.2 & 0.17 & 18 & 1.6 & 0.28 \\
\hline $\mathrm{Se}$ & Chokka & 10 & 2.8 & 0.63 & 15 & 2.8 & 0.35 \\
\hline $\mathrm{Rb}$ & Sardine & 12 & 3.6 & 0.26 & 18 & 3.1 & 0.25 \\
\hline $\mathrm{Rb}$ & Chokka & 10 & 11 & 0.82 & 15 & 8.4 & 1.2 \\
\hline $\mathrm{Sr}$ & Sardine & 12 & 5.1 & 2.9 & 18 & 5.7 & 1.7 \\
\hline $\mathrm{Sr}$ & Chokka & 10 & 15 & 2.5 & 15 & 13 & 2.0 \\
\hline Mo & Sardine & 12 & 0.056 & 0.025 & 18 & 0.49 & 0.22 \\
\hline Mo & Chokka & 10 & 0.034 & 0.0079 & 15 & 0.038 & 0.011 \\
\hline $\mathrm{Cd}$ & Sardine & 12 & 0.18 & 0.13 & 18 & 0.30 & 0.17 \\
\hline $\mathrm{Cd}$ & Chokka & 10 & 1.8 & 1.3 & 15 & 2.7 & 2.2 \\
\hline TI & Sardine & 12 & 0.034 & 0.028 & 17 & 0.11 & 0.022 \\
\hline $\mathrm{TI}$ & Chokka & 10 & 0.21 & 0.085 & 14 & 0.21 & 0.044 \\
\hline
\end{tabular}


ANOVAs for the three chokka collection sites indicated significantly (Kruskal-Wallis, oneway ANOVA; $\mathrm{p}<0.05$ ) higher median concentrations of $\mathrm{V}, \mathrm{Mn}, \mathrm{Rb}$, and $\mathrm{Sr}$ in CCS1.

Significantly (Kruskal-Wallis, one-way ANOVA; $p<0.05$ ) higher concentrations of Ti were found in CCS2 and CCS3. Other mean elemental concentrations were not significantly different between the chokka collection sites.
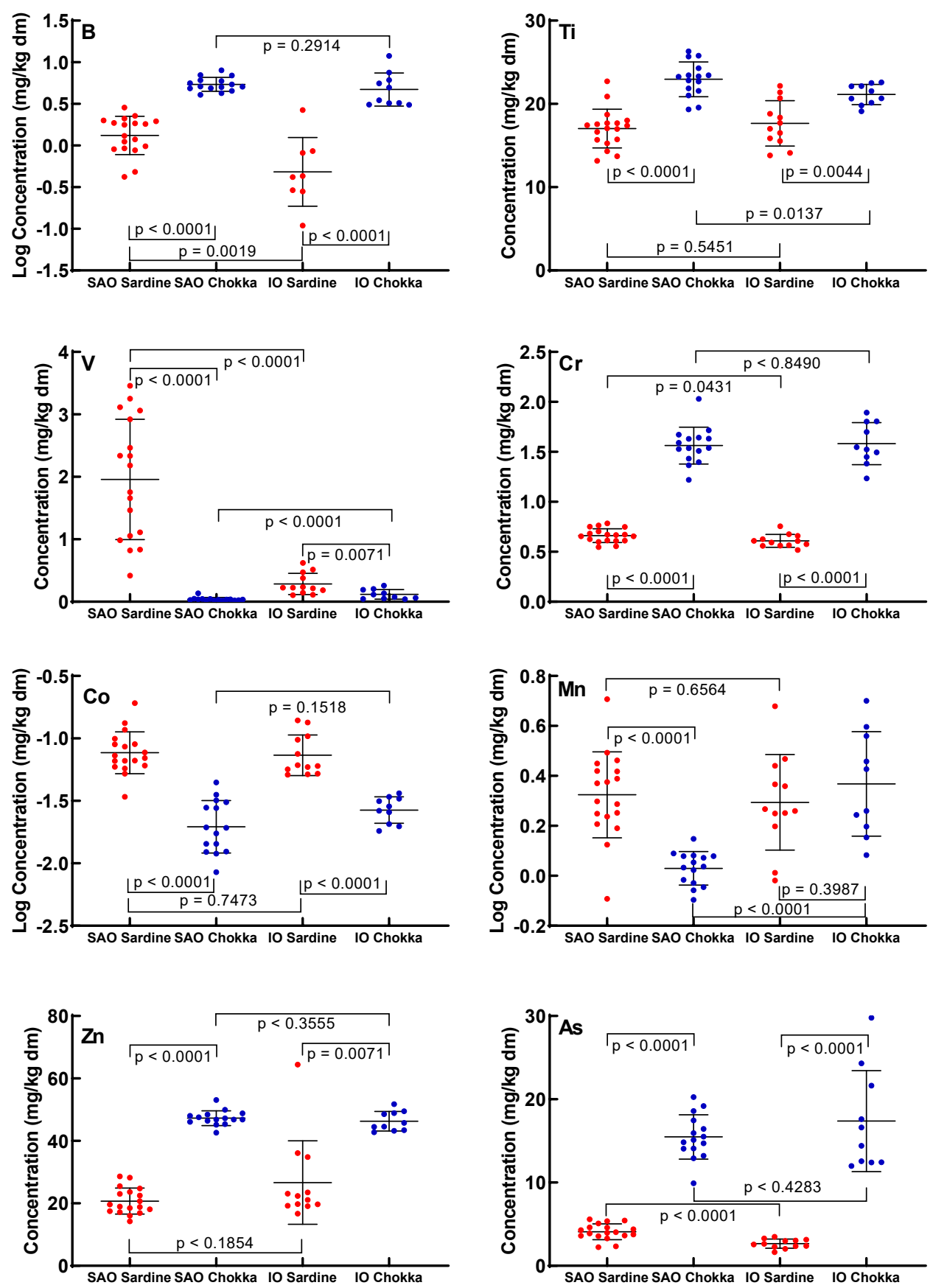

Fig. 2. Scatterplots and results of two-way, unpaired t-tests between logical pairs for elements that showed significant differences: Between sardines (red symbols) from each ocean, between chokka (blue symbols) from each ocean, and between sardines and chokka from the same ocean. Means and standard deviations are indicated. SAO = South Atlantic Ocean; $1 \mathrm{O}=$ Indian Ocean. 

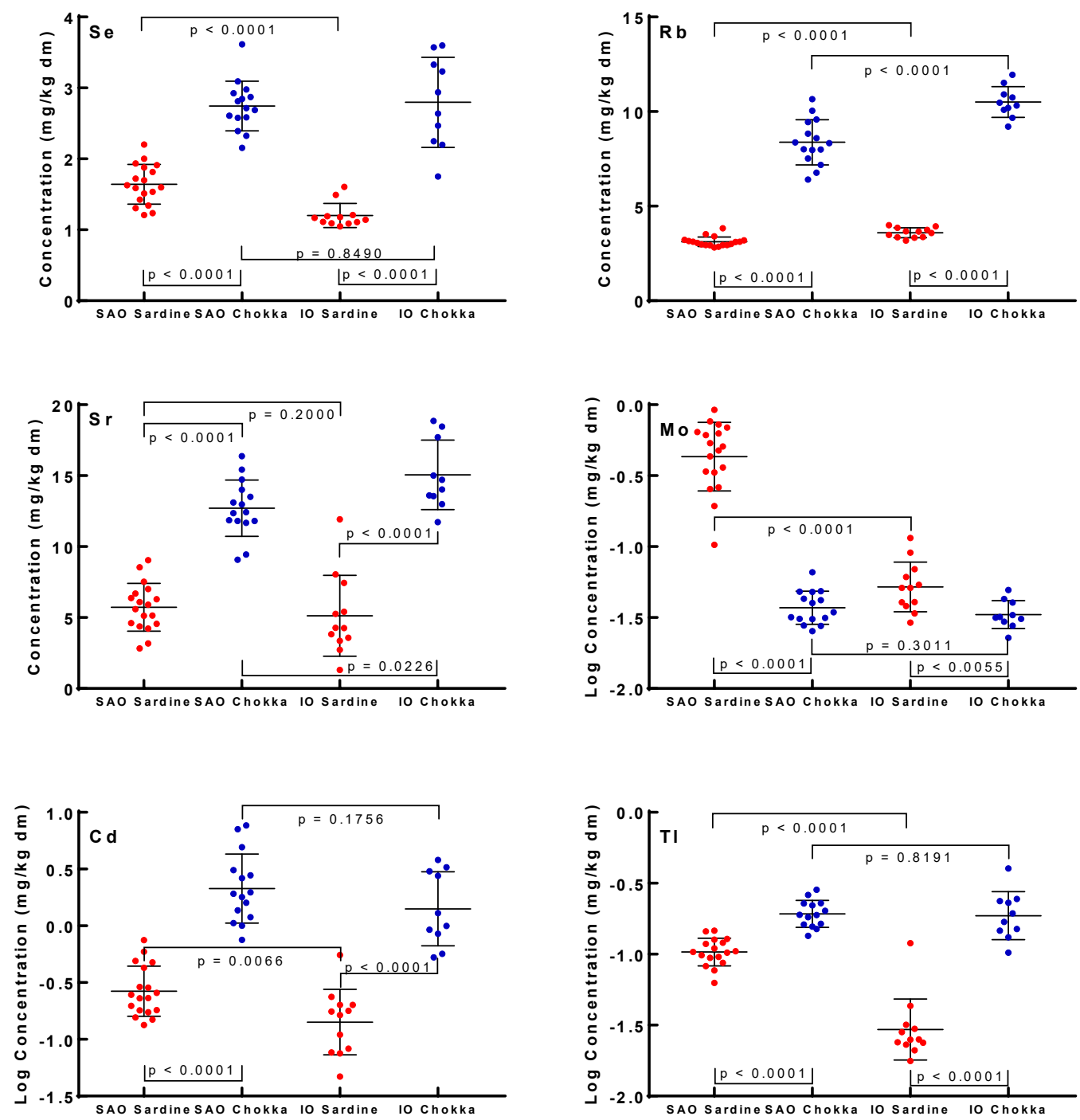

Fig. 3. Scatterplots and results of two-way, unpaired, t-tests between logical pairs for elements that showed significant differences: Between sardines (red symbols) from each ocean, between chokka from each ocean, and between sardines and chokka from the same ocean. Means and standard deviations are indicated. SAO = South Atlantic Ocean; $I O=$ Indian Ocean. 


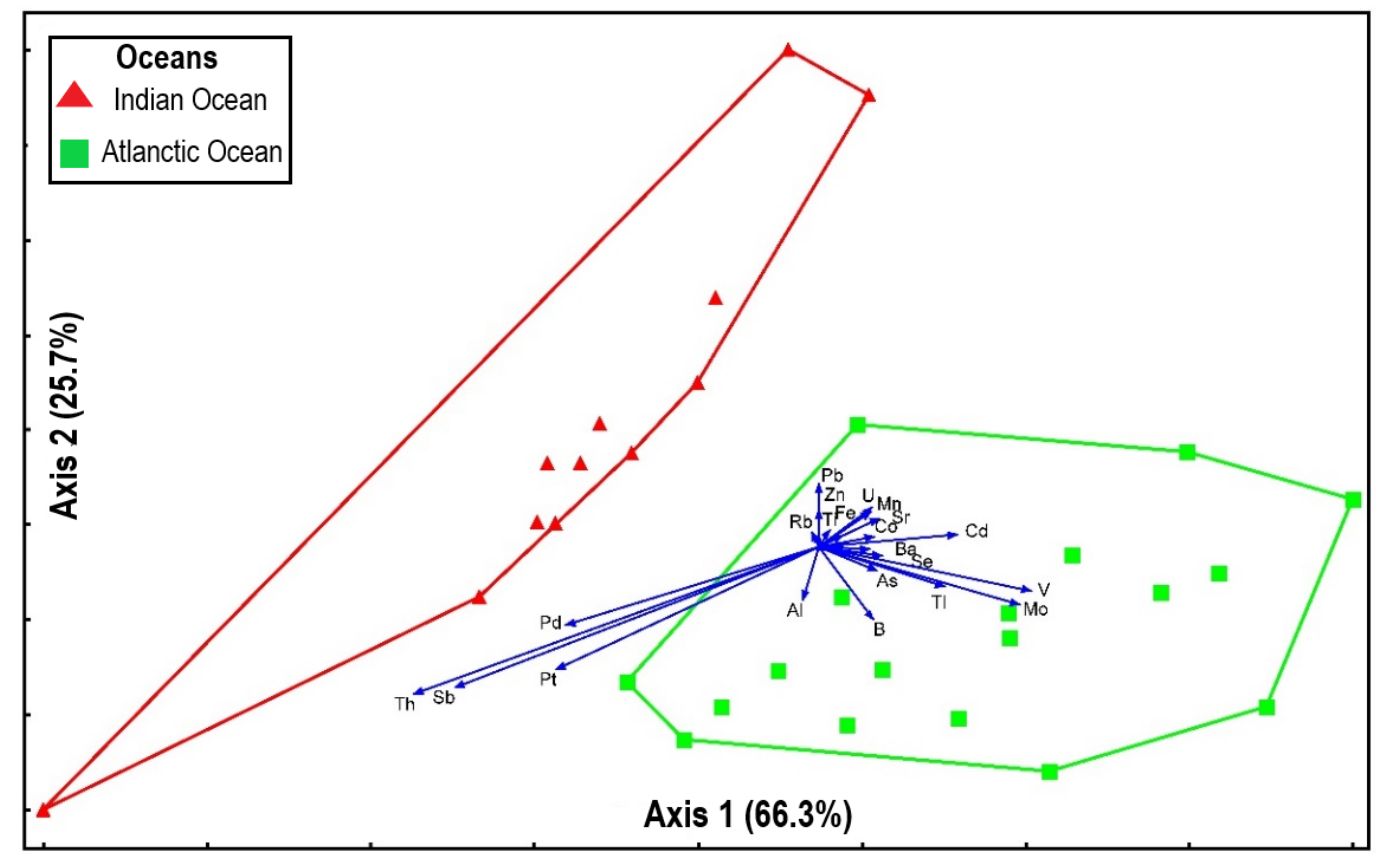

Fig. 4. Nonmetric multidimensional scaled (NMS) ordination of relativized metal concentrations (using Gower- ignore-0 as distance measure) for sardine muscle tissue.

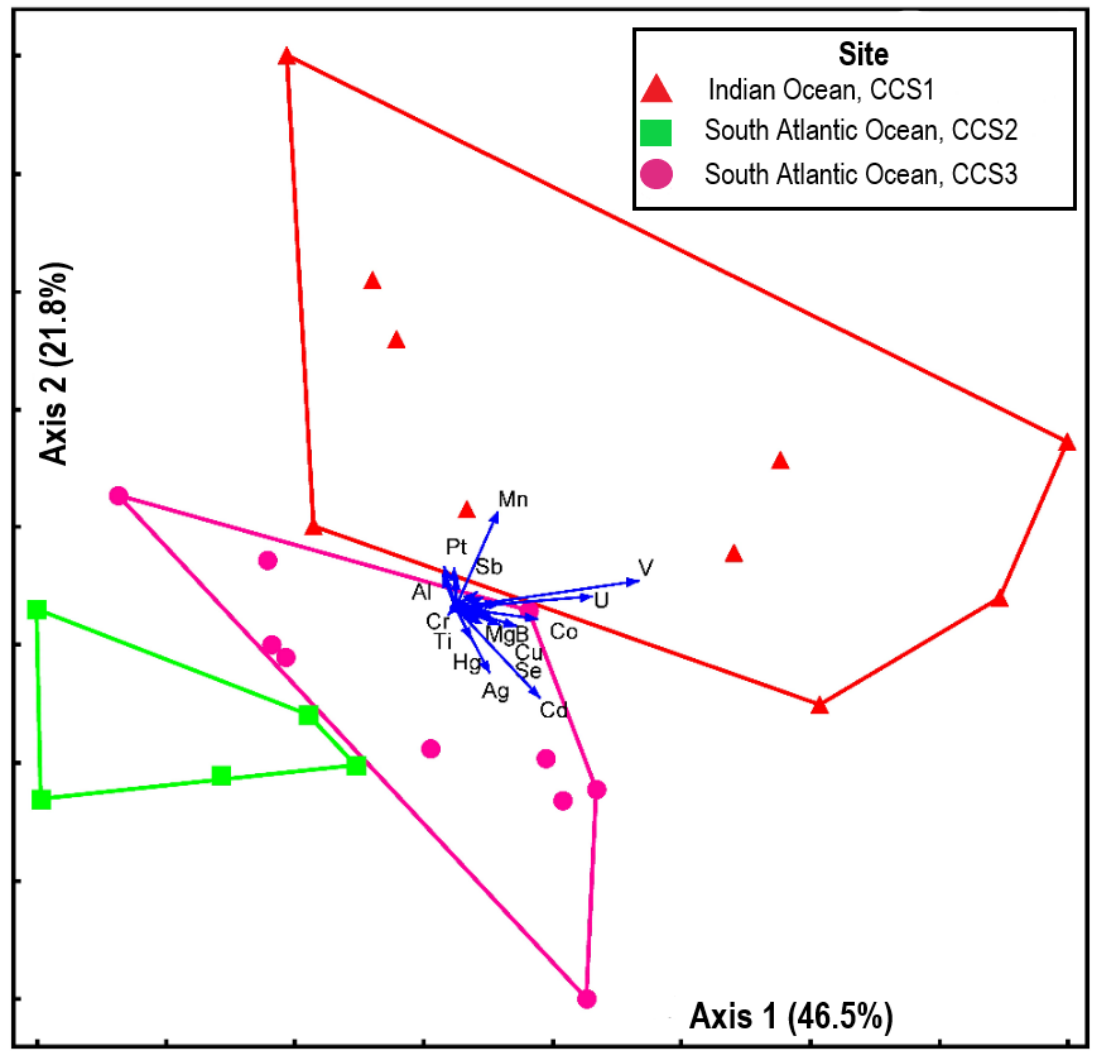

Fig. 5. Nonmetric multidimensional scaled (NMS) ordination of relativized metal concentrations (using Gower- ignore-0 as distance measure) for chokka mantle tissue. 


\section{Discussion}

\subsection{Concentration differences between sardines from different oceans}

Oceanographic conditions along the South African coast vary substantially both in time and space (Hutchings et al., 2009; Hampton et al., 2018) influencing the occurrence and numbers even of such widespread species as the sardine. Human activities may also influence the occurrence of various species, as will be discussed in section 4.3.

We found that sardine muscle tissue had significantly higher mean concentrations of Mo, $\mathrm{Cd}, \mathrm{TI}, \mathrm{B}, \mathrm{V}, \mathrm{Cr}, \mathrm{As}$, and Se in the South Atlantic Ocean compared with the Indian Ocean, while the reverse was true for $\mathrm{Rb}$ (Figures 2 and 3 ). Metallic element concentrations in organisms can be influenced by age, sex, size, feeding habits, and habitats (Griboff et al., 2018). For instance, B occurs at higher concentrations in zooplankton than in phytoplankton (EPA, 1998).

SCS2 was in the South Atlantic Ocean, which is known for upwelling events during austral spring and summer (Hutchings et al., 2009). Upwelling is known to increase metallic elements (especially Cd) in water (Jiang et al., 2017) which can then be incorporated into fish muscle tissue and otoliths. This seasonal upwelling would result in increased plankton and hence more food for sardines (Bode et al., 2018). Since plankton take up metallic elements effectively from their environment (Sanders and Riedel, 1998), sardines at SCS2 may be exposed to higher concentrations via plankton compared with sardines from SCS1.

Sardines are primarily indiscriminate filter feeders. While phytoplankton is the most commonly-ingested prey, zooplankton provides most of the fish's sustenance in both the South Atlantic and Indian oceans (van der Lingen, 2002). Spatial variability in sardine diet is apparent, with phytoplankton and smaller zooplankton more important in the South Atlantic Ocean (van der Lingen, 2002; Idris et al., 2016). This difference in diet, and spatial differences in natural background concentrations arising from different oceanographic conditions and anthropogenic sources, may explain the differences in sardine muscle metallic concentrations between collection sites. Similar background concentrations (Newman and Watling, 2007) or physiological regulation (Emsley, 2003) may explain the lack of significant differences of other elements.

\subsection{Concentration differences between chokka from different oceans}

Significant differences were found for $\mathrm{V}, \mathrm{Mn}, \mathrm{Rb}, \mathrm{Sr}$ and, Ti between chokka collection sites (Table 2). Vanadium, Mn, Rb, and Sr had significantly $(p<0.05)$ higher concentrations in the Indian Ocean, and Ti had a significantly $(p<0.05)$ higher concentration in the South Atlantic Ocean. As mentioned in section 4.1, the species included in this study are exposed to an ever-changing environment in the oceans around South Africa, and we show clear mean concentration differences. Apart from the natural background levels, the geographic distribution of anthropogenic sources (discussed in 4.3) of elements probably also explains the differences found. 


\subsection{Possible sources}

\subsubsection{Geological background}

The predominant geology of the land mass close to the catch sites is dominated by the Cape Supergroup that can be subdivided into three groups the Table Mountain Group, the Bokkeveld Group, and the Witteberg Group (Shone and Booth, 2005). These groups are mostly made up sedimentary rocks containing quartz and quartz arenites (Shone and Booth, 2005). These groups would mostly contribute $\mathrm{Si}, \mathrm{Na}, \mathrm{Ca}$, and $\mathrm{Al}$ to the surrounding waters as these elements are the most abundant minerals found in quartz (Klein and Philpotts, 2013). The fairly uniform geology of the mainland does not provide an explanation for the differences in metal concentrations found in this study.

\subsubsection{Anthropogenic sources}

Natural processes are not the only factor that affect the elemental composition of the world's oceans. South Africa is a mineral-rich country (V, Mn, and Ti [DMR, 2008, 2013]) and a high proportion of her income is derived by the mining and processing of metals (Minerals Council of South Africa, 2018). Metals from combustion, consumer products, and other sources (Table 2) can enter rivers and eventually oceans through run-off and atmospheric deposition (AMAP, 2005; Odiyo, et al., 2005; Dallas and Day, 2004; Fatoki and Mathabatha, 2001). Terrestrial and freshwater pollution, which is widely reported in South Africa (Wepener and Degger, 2012; O'Donoghue and Marshall, 2003), could therefore have affected the concentrations found in our study.

For instance, the Port Elizabeth and Kouga harbours and associated estuaries are potential sources of metals to the Indian Ocean from industries and ore loading ( $\mathrm{Nel}$ et al., 2015; Fig. 1). Hence, we expected higher metallic element concentrations at the nearby sardine and chokka collection sites, which, indeed, we found for $\mathrm{Pb}$ in sardines from SCS1 (Table S1).

Table 2. Possible anthropogenic sources of metals that were significantly different between sites and species in oceans.

\begin{tabular}{|c|c|c|}
\hline $\begin{array}{l}\text { Metallic } \\
\text { elements }\end{array}$ & Possible anthropogenic sources & References \\
\hline $\mathrm{B}$ & $\begin{array}{l}\text { Combustion of coal and biomass, soap, fertilizer, and flame } \\
\text { retardants }\end{array}$ & $\begin{array}{l}\text { Park and Schlesinger, } \\
2002 .\end{array}$ \\
\hline $\mathrm{Ti}$ & Mining, manufacturing of paints, fiber, and cosmetics & $\begin{array}{l}\text { Reimann and de Caritat, } \\
1998\end{array}$ \\
\hline $\mathrm{V}$ & Mining and the combustion of petroleum and coal & Schelsinger et al., 2017 \\
\hline $\mathrm{Cr}$ & Electroplating, paint, agriculture, combustion of fossil fuels and waste & $\begin{array}{l}\text { He et al., } 2005 \text {, Mzimela } \\
\text { et al., } 2014\end{array}$ \\
\hline $\mathrm{Mn}$ & Mining, dry cell batteries, and animal feed & Richir and Gobert, 2016 \\
\hline $\mathrm{Zn}$ & Agriculture (pesticide), wastewater, and galvanic industry & $\begin{array}{l}\text { Neff, } 2002 \text {, van Aswegen } \\
\text { et al., } 2019\end{array}$ \\
\hline As & Timber treatment, agriculture(pesticide) and burning of fossil fuels & $\begin{array}{l}\text { Tchonwou et al., 2012, } \\
\text { Lesch and Bouwman., } \\
2018\end{array}$ \\
\hline $\mathrm{Se}$ & Mining, agriculture and combustion of fossil fuel & Wen and Carignan, 2007 \\
\hline Mo & Mining and agricultural runoff & $\begin{array}{l}\text { Reimann and de Caritat, } \\
1998\end{array}$ \\
\hline $\mathrm{Cd}$ & $\begin{array}{l}\text { Batteries, paints, agricultural runoff, mining and the combustion of } \\
\text { fossil fuels }\end{array}$ & Yuan et al., 2019 \\
\hline $\mathrm{TI}$ & Mining and coal combustion & Karbowska, 2016 \\
\hline
\end{tabular}


Although naturally occurring in the ocean, Cd, As, TI, Mo, and Se can be anthropogenically increased by mining and industry (Karbowska, 2016; Kehrig et al., 2013; Oremland and Stolz, 2003; Satarug et al., 2003). These elements occurred at higher concentrations in sardines collected in the South Atlantic, and Cd was also higher for chokka there compared to the Indian Ocean. Although upwelling could have caused the higher concentrations, this does not dismiss the possible contribution from anthropogenic sources.

Large deposits of Mn are found in the North Cape (west coast) (DMR, 2013) which could have affected the concentrations found in our study. However, this was not the case as significantly higher concentrations of Mn were found in chokka from the Indian Ocean (CCS1). This could be due to the influence of Mn nodules found in the mid-Indian Ocean (Bollman et al., 2010).

Our data therefore indicate that the concentrations found in our study cannot be attributed to either natural background or anthropogenic activity as major sources, but rather a combination of these two, the relative contributions of which we do not know. Indications of relative contributions may be needed when comparing anthropogenic and natural halogenated organic compounds with metals in marine organisms from the two oceans (Aznar-Alemany et al., 2019; Bouwman et al., 2015; Van Aswegen et al., 2019; Wu et al., 2019).

\subsection{Differences in concentrations between sardine and chokka}

We found significantly higher ( $p<0.001$ ) concentrations of B, Ti, Cr, Zn, As, Se, Rb, Sr, $\mathrm{Cd}$, and $\mathrm{TI}$ in chokka when compared with sardines (Figures 2 and 3 ), suggesting accumulation in chokka from their prey. Loliginid species are believed to accumulate most of their metallic elements via the trophic pathway (Penicaud, 2017). Other prey items are likely to reflect similar local conditions, contributing towards consistently higher concentrations and accumulation in chokka, despite inter-ocean differences. However, sardines had significantly $(p<0.001)$ higher concentrations of $\mathrm{Mn}, \mathrm{Mo}, \mathrm{V}$, and Co than chokka, suggesting physiological regulation by either or both. A contributing explanation could be that that Co and $V$ accumulate in the brachial heart of loliginid species (Penicaud, 2017) and may cause these elements to be lower in the muscle tissue.

Manganese is incorporated into loliginid eggs (Penicaud, 2017) suggesting a possible reason why $\mathrm{Mn}$ concentrations were lower in the chokka mantle tissue as these samples were caught in the austral summer when chokka lay their eggs. Chokka could also incorporate these elements into the gladius - this, however, has not been tested before. Different tissues should be analysed in the future as loliginids build up stores of metallic elements in the brachial heart and the digestive gland (Penicaud, 2017). This information could be crucial in understanding the accumulation of metallic elements in squids in general.

No study has been done on the relationship of metallic elements in muscle tissue between sardine and any squid in the Southern Hemisphere. Comparison with studies from elsewhere indicates similarities and differences (Table 3). Rubidium has been found at higher concentrations in higher trophic levels in aquatic ecosystems (Campbell et al., 2005a, b). Zinc has been shown to accumulate through trophic levels by several studies, some using stable isotope analyses (Campbell et al., 2005b; Chen et al., 2000; Quinn et al., 2003; Trevizani et al., 2018; Tu et al., 2012). Lower concentrations in higher trophic levels have been found for Mn (Griboff et al., 2018; Hao et al., 2013).

On the other hand, and contrary to our findings, other studies found lower concentrations in higher trophic levels for Zn (Besser et al., 2001; Jara-Marini et al., 2009; Borrell et al., 
2016), Cd (Guo et al., 2016; Campbell et al., 2005b), Cr (Revenga et al., 2012), and As (Trevizani et al., 2018; Chen et al., 2000). Differences in food web structure, and probably differences in the physiologies of molluscs (chokka) and vertebrates (sardine), where invertebrate molluscs feed on vertebrates, are likely contributory factors. Little information is available about the possible accumulation B, TI, Se and, Sr; more research on the trophic differences of these elements is required.

Our data are not directly comparable with the findings of others, as different trophic systems may react to metallic elements in different ways. Analysing more samples, more species from more trophic levels (e.g., plankton, sharks, and tuna) from more sites, and increasing the number of samples from different trophic levels within the same systems (the Indian and South Atlantic oceans in this case) would be needed for clarification.

\subsection{Multivariate analyses of relative elemental compositions of sardine and chokka per collection site}

Clear 'fingerprint' differences in metallic element compositions were seen between the two sardine sites (Figure 4). These differences can be attributed to many factors mentioned in section 4.1 and 4.3. Although we only had two sardine sampling sites, our data supports the hypothesis of multiple sardine stocks off South Africa. Multiple stocks are also implied by other studies that compared morphometric, meristic, genetic, and parasite load characteristics of sardines from the west, south, and east coasts (Groenewald et al., 2019; Idris et al., 2016; Teske et al., 2018; van der Lingen et al., 2015; Weston et al., 2015). A recent study (Hampton et al., 2018) showed that otolith microchemistry of South African sardine juveniles differed between collection sites in the same ocean - most of the compositional differences were site specific and varied annually. Our study had a smaller sample size and only two collection sites and could not indicate if these differences were gradual (supporting a single stock assumption) or discontinuous (indicating multiple stocks) along the coast of South Africa. Larger samples sizes and more collection sites would confirm and be able to track different stocks using muscle tissue elemental concentrations as an easy alternative to otolith microchemistry, morphometrics, and parasite composition, or complement these methods.

Chokka collection sites had relative elemental composition profiles that did not overlap (Figure 5), and ANOVAs and t-tests showed that only a few elements ( $\mathrm{V}, \mathrm{Mn}, \mathrm{Rb}, \mathrm{Ti})$ differed in mean concentration between the collection sites. These differences in compositions could be explained by different prey at the different collection sites, as prey is a crucial pathway of metallic elements in loliginids. Although spatial differences in metallic element compositions in chokka were not as large as those seen in sardines, the non-overlapping compositions (Figure 5) between chokka collection sites supports the hypothesis of multiple stocks in this species. Chokka from around southern Africa appear to be genetically uniform (Shaw et al., 2010) but show significant morphometric diversity (van der Vyver et al., 2015), leading to the hypothesis that chokka off southern Africa is a large and mobile metapopulation, that comprises three main geographic groups, two of which are off South Africa (Lipinski et al., 2016). Again, data from more samples from more sites would be needed to confirm this. 


\subsection{Comparisons with similar studies}

We selected three well-known toxic metals that are regularly reported in literature $(\mathrm{Cd}$, $\mathrm{Pb}, \mathrm{Hg}$ ) and compared our findings with other studies (Table 3). Studies were chosen with similar taxa as this is the first time metallic elemental data is presented for Loligo reynaudii, and only the third study published on Sardinops sagax. Loligo vulgaris was chosen as the species to compare to chokka as $L$. reynaudii was previously classified as a subspecies of $L$. vulgaris. Sardina pilchardus was chosen as another comparative species for sardine because of its similar feeding habits as Sardinops sagax (Garrido and van der Lingen, 2014). Sardines from the South Atlantic Ocean (SCS2) and Indian Ocean (SCS1) collection sites had the second and third highest $\mathrm{Cd}$, and third and second highest $\mathrm{Pb}$ concentrations of the studies that were compared. Only two of our sardine samples had quantifiable $\mathrm{Hg}$, and these values were the lowest of all the studies we compared. Cadmium concentrations in chokka were the highest, and $\mathrm{Hg}$ the second highest, when compared with other studies, indicating either a high natural background, pollution, or both.

Table 3 Global comparison of $\mathrm{Hg}, \mathrm{Pb}$ and $\mathrm{Cd}(\mathrm{mg} / \mathrm{kg} \mathrm{wm}$ ) in sardine (Sardina pilchardus and Sardinops sagax) and chokka (Loligo vulgaris and L. reynaudii) with limits set by the European Union (EU) and the South African government for these metals.

\begin{tabular}{|c|c|c|c|c|c|}
\hline Species & Location & Cd & $\mathbf{P b}$ & $\mathrm{Hg}$ & Reference \\
\hline Sardina pilchardus & Adriatic Sea & 0.02 & 0.03 & 0.07 & Storeli (2008) \\
\hline Sardina pilchardus & North Atlantic Ocean & 0.024 & 0.076 & 0.084 & Chahid et al. (2014) \\
\hline Sardina pilchardus & Atlantic Ocean & 0.0064 & 0.03 & 0.019 & Viera et al. (2011) \\
\hline Sardina pilchardus & Mediterranean Sea & $0.002-0.1$ & $0.01-0.08$ & $0.07-0.09$ & Falco et al. (2006) \\
\hline Sardinops sagax & Bass Strait (Australia) & 0.096 & 0.013 & 0.034 & Finger et al. (2017) \\
\hline Sardinops sagax & Bass Strait (Australia) & 0.018 & 0.034 & 0.034 & Finger et al. (2017) \\
\hline Sardinops sagax & Arabian Gulf & 0.037 & 0.005 & $<L O Q$ & Tawfik (2013) \\
\hline Sardinops sagax & Indian Ocean (SCS1) & 0.052 & 0.052 & 0.0049 & This study \\
\hline Sardinops sagax & South Atlantic Ocean (SCS2) & 0.078 & 0.044 & 0.00057 & This study \\
\hline EU limits (Sardine) & & 0.25 & 0.3 & 0.5 & EU (2006; 2014) \\
\hline RSA limits (Sardine) & & 1 & 0.5 & 0.5 & South Africa (1997) \\
\hline Loligo vulgaris & Adriatic Sea & 0.26 & 0.03 & 0.02 & Storeli (2008) \\
\hline Loligo vulgaris & Mediterranean Sea & $0.05-0.15$ & $0.01-0.01$ & $0.02-0.03$ & Falco et al. (2006) \\
\hline Loligo vulgaris & Pacific Ocean & 0.29 & 0.04 & $<L O Q$ & Sangiuliano et al. (2017) \\
\hline Loligo vulgaris & Mediterranean Sea & 0.3 & 0.05 & 0.11 & Storeli (2010) \\
\hline Loligo reynaudii & Indian Ocean (CCS1) & 0.38 & 0.04 & 0.03 & This study \\
\hline Loligo reynaudii & South Atlantic Ocean (CCS2) & 0.72 & 0.036 & 0.056 & This study \\
\hline Loligo reynaudii & South Atlantic Ocean (CCS3) & 0.66 & 0.04 & 0.05 & This study \\
\hline EU limits (Chokka) & & 1 & 1 & 0.5 & EU, 2006; EU, 2014 \\
\hline RSA limits (Chokka) & & 3 & 4 & 0.5 & South Africa, 1997 \\
\hline
\end{tabular}

\subsection{Seafood safety}

Metal concentrations found in muscle tissue of sardine and chokka did not exceed the limits (despite marginal exceedances for $\mathrm{Cd}$ in two chokka samples) set by both the European Union (EU) and the South African government (Table 3) for $\mathrm{Pb}, \mathrm{Hg}$ and $\mathrm{Cd}$. No 
other elements have similar standards except for Sn, but this is for canned fish only, hence not applicable here.

Estimated daily intakes (EDIs) and total hazard quotients (THQs) were calculated according to the formulae used by Beheary and El-Matary (2018). The average mass and lifespan of a South African resident was selected at $70 \mathrm{~kg}$ and 72.7 years, respectively. The daily intake of sardine was estimated to be $0.0006 \mathrm{~kg} / \mathrm{day}$, and the chokka daily intake was estimated to be at $0.00018 \mathrm{~kg} /$ day for South African residents (WWF, 2014). The THQ values (Table 4) were all orders of magnitude below the quotient of unity and would thus pose no threat to consumers based on our assumptions. For $\mathrm{Cd}, \mathrm{Pb}$, and $\mathrm{Hg}$, sardine and chokka should be considered safe for human consumption and export, but more samples from more locations would add weight to our findings.

Table 4: Estimated daily intakes (EDIs) and total hazard quotients (THQs) for cadmium, lead and mercury measured in sardine and chokka from each catch site.

\begin{tabular}{lllllll}
\hline Catch sites & Cd EDI & Cd THQ & Pb EDI & Pb THQ & Hg EDI & Hg THQ \\
\hline SCS1 & 0.0000043 & 0.0043 & 0.0000043 & 0.0012 & 0.00000040 & 0.00013 \\
SCS2 & 0.0000064 & 0.0064 & 0.0000036 & 0.0010 & 0.000000047 & 0.000016 \\
CCS1 & 0.00000094 & 0.00094 & 0.0000001 & 0.000029 & 0.000000074 & 0.000047 \\
CCS2 & 0.0000018 & 0.0018 & 0.000000074 & 0.000021 & 0.00000014 & 0.00004 \\
CCS3 & 0.0000016 & 0.0016 & 0.0000001 & 0.000029 & 0.00000012 & 0.028 \\
\hline
\end{tabular}

\section{Conclusions}

Globally, marine fish and cephalopods are important food sources and are ecologically important. This is the first study to report on the metallic element composition in sardine muscle and chokka mantle tissues from the African coast, with previous studies only done on $\mathrm{Hg}$ in seafood in South African supermarkets (Bosch et al., 2016).

Different sites showed considerable differences in metallic element composition for sardines and chokka. Due to different oceanographic conditions around South Africa, with upwelling substantially more important on the west coast, the background concentrations of metals may vary, resulting in variable metal concentrations in fish and squid.

Although based on only two collection sites, metallic element concentration differences did not contradict a multiple stock assumption for sardine. Although spatial differences in chokka metallic element composition were not as marked as in sardine, our data also support a multiple stock hypothesis for chokka. Metallic elements could therefore be investigated as a stock discrimination tool for both of these species. Boron $\mathrm{Cr}, \mathrm{Zn}, \mathrm{As}$, Se, $\mathrm{Rb}, \mathrm{Sr}, \mathrm{Cd}$, and, $\mathrm{TI}$ had significantly higher $(\mathrm{p}<0.0001)$ concentrations in chokka than sardines, indicating possible accumulation by chokka. Vanadium, $\mathrm{Mn}, \mathrm{Ti}$, and, Mo concentrations were significantly lower $(p<0.0001)$ in chokka than sardines, indicating physiological regulation of these elements in chokka.

Chokka and sardines from South Africa, although based on a limited sample size, can be considered safe for human consumption in terms of the concentrations of $\mathrm{Pb}, \mathrm{Hg}$, and $\mathrm{Cd}$. We recommend that future studies of the metallic element composition of South African marine biota increase the number of species from different trophic levels, increase the number of sites, and use larger sample sizes to investigate trophic level interactions and the utility of this method as a stock discrimination tool for fisheries management. 


\section{Acknowledgements}

We thank G. Kant, G. Jarvis and C. Hart (Department of Agriculture, Forestry and Fisheries) for providing the samples used in this study. We thank Caitlin Swiegelaar, and the POPT editorial collective, for improvements to the manuscript. We thank the National Research Foundation (NRF) of South Africa for funding. Opinions expressed, and conclusions arrived at are those of the authors and are not necessarily to be attributed to the NRF.

\section{References}

AMAP, 2005. AMAP Assessment 2002: Heavy Metals in the Arctic. Arctic Monitoring and Assessment Programme (AMAP), Oslo, Norway.

Augustyn, C.J., Lipinski, M.R., Sauer, W.H.H., Roberts, M.J., Mitchell-Innes, B.A. 1994. Chokka squid on the Agulhas Bank: life history and ecology. South African Journal of Science. 90, 143-154.

Aznar-Alemany, Ò., Sala, B., Plön, S., Bouwman, H., Barceló, D., Eljarrat, E. 2019. Halogenated and organophosphorus flame retardants in cetaceans from the southwestern Indian Ocean. Chemosphere. 226, 791-799.

Beckley, L.E., van der Lingen, C.D. 1999. Biology, fishery and management of sardines (Sardinops sagax) in southern African waters. Marine and Freshwater Research. 50, 955978.

Beheary, M.S. and El-Matary, F.A. 2018. Bioacumulation of heavy metals and implications associated with consumption of the Thinlip Mullet (Liza ramanda) collected from sites of varying salinity. Asian Journal of Fisheries and Aquatic Research. 2, 1-15.

Besser, J.M., Brumbaugh, W.G., May, T.W., Church, S.E., Kimball, B.A. 2001. Bioavailability of metals in stream food webs and hazards to brook trout (Salvelinus fontinalis) in the upper Animas River watershed, Colorado. Archives of the Environmental Contamination and Toxicology. 40, 48-59.

Bode, A., Carrera, P., Gonzalez-Nuevo, G., Nogueria, E., Riveiro, I., Santos, M.B. 2018. A trophic index for sardine (Sardina pilchardus) and its relationship to population abundance in the southern Bay of Biscay and adjacent waters of the NE Atlantic. Progress in Oceanography. 166, 139-147.

Bollmann, M., Bosch, T., Colijn, F., Ebinghaus, R., Froese, R., Guessow, K., Khalilian, S., Krastel, S., Koertzinger, A.,Lagenbuch, M., Latif, M., Matthiessen, B., Melzner, F., Oschlies, A., Petersen, S., Proelss, A., Quaas, M., Reichenbach, J., Requate, T., Reusch, T., Rosenstiel, P., Schmidt, J. O., Schrottke, K., Sichelschmidt, H., Siebert, U., Soltwedel, R., Sommer, U., Stattegger, K., Sterr, H.,Sturm, R., Truede, T., Vafeidis, A., Van Bernem, C., Van Beusekom, J., Voss, R., Visbeck, M.,Wahl, M., Wallmann, K., Weinberger, F. 2010. Marine Ocean review: Living with the oceans. Hamburg, Germany: Maribus.

Borrell, A., Tornero, V., Bhattacharjee, D., Aguilar, A. 2016. Trace element accumulation and trophic relationships in aquatic organisms of the Sundarbans mangrove ecosystem (Bangladesh). Science of the Total Environment. 545-546, 414-423.

Bosch, A.C., O'Neill, B.O., Sigge, G.O., Kerwath, S.E., Hoffman, L.C. 2016. Mercury accumulation in Yellowfin tuna (Thunnus albacares) with regards to muscle type, muscle position and fish size. Food Chemistry. 190, 351-356. 
Bouwman, H., Govender, D., Underhill, L., Polder, A. 2015. Chlorinated, brominated and fluorinated organic pollutants in African Penguin eggs: 30 years since the previous assessment. Chemosphere. 126, 1-10.

Campbell, L.M., Fisk, A.T., Wang, X., Köck, G., Muir, D.C.G. 2005. Evidence for biomagnification of rubidium in freshwater and marine food webs. Canadian Journal of Fisheries and Aquatic Sciences. 62, 1161-1167.

Campbell, L.M., Norstrom, R.J., Hobson, K.A., Muir, D.C.G., Backus, S., Fisk, A.T. 2005. Mercury and other trace elements in a pelagic Arctic marine food web (Northwater Polynya, Baffin Bay). Science of the Total Environment. 351-352, 247-263.

Chahid, A., Hilali, M., Benlhachimi, A., Bouzid, T. 2014. Contents of cadmium, mercury and lead in fish from the Atlantic sea (Morocco) determined by atomic absorption spectrometry. Food Chemistry. 147, 357-360.

Chen, C.Y., Stemberger, R.S., Klaue, B., Blum, J.D., Pickhardt, P.C., Folt, C.L. 2000. Accumulation of heavy metals in food web components across a gradient of lakes. Limnology and Oceanography. 45, 1525-1536.

Connan, M., Bonnevie, B.T., Hagen, C., van der Lingen, C.D., McQuiad, C. 2017. Diet specialization in a colonial seabird studied using three complementary dietary techniques: effects of intrinsic and extrinsic factors. Marine Biology.164, 171.

DAFF (Department of Agriculture, Forestry and Fisheries). 2016. Status of the South African Marine Fishery Resources 2016. Cape Town, DAFF, 91+viii pp.

Dallas, H.F., Day, J.A. 2004. The effect of water quality variables on aquatic ecosystems: a review. WRC Report No. TT 224/04

Du Preez, M., Nel, R., Bouwman, H. 2018. First report of metallic elements in loggerhead and leatherback turtle eggs from the Indian Ocean. Chemosphere. 197, 716-728.

DMR (South Africa Department of Mineral Resources) 2008. An overview of South Africa's vanadium industry during the period 1997-2006. Report R55/2008.

DMR (South Africa Department of Mineral Resources) 2013. South Africa's manganese industry developments, 2004-2011. Report R102/2013.

Emsley, J. 2003. Nature's building blocks. Oxford: Oxford University Press, Oxford.

EU (European Union). 2006. Commission regulation (EC) No 1881/2006 of 19 December 2006

EU (European Union). 2014. Commission regulation (EU) No 488/2014 of 14 May 2014

Falco, G., Llobet, J.M., Bocio, A., Domingo, J.L. 2006. Daily intake of arsenic, cadmium, mercury, and lead by consumption of edible marine species. Journal of Agricultural and Food Chemistry. 54, 6106-6112.

Fatoki, O.S. and Mathabatha, S. 2001. An assessment of heavy metal pollution in the East London and Port Elizabeth harbours. Water South Africa.27, 233-240.

Fernandez, W.S., Dias, J.F., Boufleur, L.A., Amaral, L., Yoneama, M.L., Dias, J.F. 2014. Bioacumulation of trace elements in hepatic and renal tissues of the white mullet Mugil curema Valenciennes, 1836 (Actinopterygii, Mugilidae) in two coastal systems in southeastern Brazil. Nuclear Instruments and Methods in Physics Research B. 318, 94-98

Finger, A., Lavers, J.L., Dann, P., Kowalczyk, N.D., Scarpaci, C., Nugegoda, D., Orbell, J.D. 2017. Metals and metalloids in Little Penguin (Eudyptula minor) prey, blood and faeces. Environmental Pollution. 223, 567-574.

Garrido, S., van der Lingen, C.D. 2014. Chapter 4. Feeding biology and ecology. In: Ganias, K. (Ed.). Biology and ecology of sardines and anchovies. CRC Press, Boca Raton, pp 122-189.

Greenfield, R., Wepener, V., Degger, N., Brink, K., 2011. Richards Bay Harbour: metal exposure monitoring over the last 34 years. Marine Pollution Bulletin. 62, 1926-1931. 
Griboff, J., Horacek, M., Wunderlin, D.A., Monferran, M.V. 2018. Bioaccumulation and trophic transfer of metals, As and Se, through a freshwater food web affected by anthropic pollution in Córoba, Argentina. Ecotoxicology and Environmental Safety. 148, 276-284

Groenewald, G., Moloney C.L., van der Lingen, C.D. 2019 Spatial variation in meristic and morphometric characteristics of sardine Sardinops sagax around the coast of southern Africa. African Journal of Marine Science.41, 51-60

Guo, B., Jiao, D., Wang, J., Lei, K., Lin, C. 2016. Trophic transfer of toxic elements in the estuarine invertebrate and fish food web of Dailio River, Liaodong Bay, China. Marine Pollution Bulletin. 113, 258-265.

Hampton, S.L., Moloney, C.L., van der Lingen, C.D., Lanonne, M. 2018. Spatial and temporal variability in otolith elemental signatures of juvenile sardine off South Africa. Journal of Marine Systems 188, 106-116.

Hao, Y., Chen, L., Zhang, X., Zang, D., Yu, Y., Fu, J. 2013. Trace elements in fish from Taihu lake, China: Levels, associated risks, and trophic transfer. Ecotoxicology and Environmental Safety. 90, 89-97.

He, Z. L., Yang, X. E., Stoffella, P. J. 2005. Trace elements in agroecosystems and impacts on the environment. Journal of Trace Elements in Medicine and Biology. 19,125-140.

Huisamen, J., Kirkman, S.P., van der Lingen, C.D., Watson, L.H., Cockcroft, V.G., Jewell, R., Pistoruis, P.A. 2012. Diet of the Cape fur seal Arctocephalus pusillus at the Robberg Peninsula, Plettenberg Bay, and the implications on local fisheries. African Journal of Marine Science. 34, 431-441.

Hutchings, I, van der Lingen C.D., Shannon, I.J., Crawford, R.J. M., Verheye, H.M. S., Bartholomae, C.H., van der Plas, A.K., Louw, D., Kreiner, A., Ostrowski, M., Fidel, Q., Barlow, R.G., Lamont, T., Coetzee, J., Shillington, F., Veitch, J., Currie, J. C., Monticiro, P.M.S. 2009. The Benguela Current: an ecosystem in four components. Progress in Oceanography. 83, 15-32.

Idris, I., Moloney C.L., van der Lingen, C.D. 2016. Spatial variability in branchial basket meristics and morphology of southern African sardine Sardinops sagax. African Journal of Marine Science. 38, 351-362

Jara-Marini, M.E., Soto-Jiménez, M.F., Páez-Osuna, F. 2009. Trophic relationships and transference of cadmium, copper, lead and zinc in a subtropical coastal lagoon good web from SE Gulf of California. Chemosphere. 77, 1366-1373.

Jiang, W., Yu, K., Song, Y., Zhao, J., Feng, Y., Wang, Y., Xu, S. 2017. Coral trace metal of natural anthropogenic influences in the northern South China Sea. Science of the Total Environment 607-608, 195-203.

Jiang, Z., Xu, N., Liu, B., Zhou, L., Wang, J., Wang, B. D., Xiong, W. 2018. Metal concentrations and risk assessment in water, sediment and economic fish species with various habitat preferences and trophic guilds from Lake Caizi, Southeast China.

Ecotoxicology and Environmental Safety. 157, 1-8.

Karbowska, B. 2016. Presence of thallium in the environment: sources of contaminations, distribution and monitoring methods. Environmental Monitoring and Assessment. 118, 640.

Kehrig, H.A., Seixas, T.G., Di Beneditto, A.P.M., Malm, O. 2013. Selenium and mercury in widely consumed seafood from South Atlantic Ocean. Ecotoxicology and Environmental Safety. 93, 156-162.

Klein, C. and Phillpots, A.R. 2013. Earth materials: Introduction to minerology and petrology. $22^{\text {nd }}$ ed. New York. Cambridge University Press.

Lesch, V. and Bouwman, H. 2018. Adult dragonflies are indicators of environmental metallic elements. Chemosphere. 209, 654-665. 
Lipinski, M. R. 1991. Cephalopods and the Benguela Ecosystem: Trophic relationships and impact. South African Journal of Marine Science. 12, 791-802.

Lipinski, M.R., van der Vyver J.S.F., Shaw, P., Sauer, W.H.H. 2016. Life cycle of chokka-squid Loligo reynaudii in South African waters. African Journal of Marine Science. 38(4): 589-593.

McCune, B., Grace, J.B., 2002. Analysis of Ecological Communities. MjM Software Design, Gleneden Beach, Oregon.

Mineral Council of South Africa. 2018. Mining in SA. http://www.mineralscouncil.org.za/samining Date of access: 26 September 2018

Mzimela, H.M., Wepener, V., Cyrus, D.P. 2014. Spatial and temporal variations in selected heavy metals in water and sediment from the Mhlathuze Esuary, Richards Bay. African Journal of Environmental Science and Technology. 8, 670-683.

Mziray, P. and Kimirei, I. A. 2016. Bioaccumulation of heavy metals in marine fishes (Siganus sutor, Lethrinus harak, and Rastrelliger kanagurta) from Dar es Salaam Tanzania. Regional Studies in Marine Science. 7, 72-80.

Neff, J. M. 2002. Zinc in the Ocean. Bioaccumulation in Marine Organisms. 175-189

Nel, L., Strydom, N.A., Bouwman, H., 2015. Preliminary assessment of contaminants in the sediment and organisms of the Swartkops Estuary, South Africa. Marine Pollution Bulletin. 101, 878-885.

Newman, B.K., Watling, R.J. 2007. Definition of baseline metal concentrations for assessing metal enrichment of sediment from the south-eastern Cape coastline of South Africa. Water SA 33, 675-691.Odiyo, J.O., Bapela, H.M., Mugwendi, R., Chimuka, L. 2005. Metals in environmental media: A study of trace and platinum group metals in Thohoyandou, South Africa. Water South Africa. 31, 581-588.

Odiyo, J.O., Bapela, H.M., Mugwendi, R., Chimuka, L., 2005. Metals in environmental media: A study of trace and platinum group metals in Thohoyandou,South Africa. Water S. Afr. 31, 581-588.

O'Donoghue, S. and Marshall, D. J. 2003. Marine pollution research in South Africa: a status report. South African Journal of Science. 99, 349-356

Oremland, R. S., Stolz, J. 2003. The ecology of arsenic. Science. 300, 939-945.

Park, H., Schlesinger, W. 2002. Global biogeochemical cycle of boron. Global Biogeochemical Cycles. 16, 20-1-20-11

Penicaud, V., Lacoue-Labarthe, T., Bustamante, P. 2017. Metal bioaccumulation and detoxification processes in cephalopods: A review. Environmental Research. 155, 123-133.

Quinn, M. R., Feng, X., Folt, C. L., Chamberlain, C. P. 2003. Analyzing trophic transfer of metals in stream food webs using nitrogen isotopes. Science of the Total Environment. 317, 73-89.

Reimann, C. and Caritat, P. 1998. Chemical Elements in the Environment. Factsheets for the Geochemist and Environmental Scientist. $9^{\text {th }}$ ed. Berlin, Heidelberg: Springer.

Revenga, J.E., Campbell, L.M., Arribére, M.A., Ribeiro Guevara, S. 2012. Arsenic, cobalt and chromium food web biodilution in a Patagonia mountain lake. Ecotoxicology and Environmental Safety. 81, 1-10.

Richir, J., Gobert, S. 2016. Trace Elements in Marine Environments: Occurrence, Threats and Monitoring with Special Focus on the Coastal Mediterranean. Journal of Environmental \& Analytical Toxicology. 6.

Sanders, J.G. and Riedel, G.F. 1998. Metal accumulation and impacts in phytoplankton. (In Langston, W.J. and Bebianno, M.J. $1^{\text {st }}$ ed Metal metabolism in aquatic environments.

London: Chapman and Hall. P. 59-71).

Sangiuliano, D., Rubio, C., Gutiérrez, A.J., González-Weller, D., Revert, C., Hardisson, A., 
Zanardi, E., Paz, S. 2017. Metal concentrations in samples of frozen cephalopods (cuttlefish, octopus, squid, and shortfin squid): An evaluation of dietary intake. Journal of Food

Protection. 80, 1867-1871.

Satarug, S., Baker, J.R., Urbenjapol, S., Haswell-Elkins, M., Reilly, P.E.B., Williams, D.J., Moore, M. R. 2003. A global perspective on cadmium pollution and toxicity in nonoccupational exposed population. Toxicology Letters. 137, 65-83.

Sauer, W.H.H., and Lipinski, M.R. 1991. Food of squid Loligo vulgaris reynaudii (Cephalopoda: Loliginidae) on their spawning grounds off the Eastern Cape, South Africa. South African Journal of Marine Science. 10, $193-201$.

Schlesinger, W., Klein, E.M., Vengosh, A., 2017. Global biogeochemical cycle of vanadium. Proceedings of the National Academy of Sciences. 114, E11092-E11100.

Shaw, P.W., Hendrickson, L., Mckeown, N.J., Stonier, T., Naud. M.J., Sauer, W.H.H. 2010 Discrete spawning aggregations of loliginid squid do not represent genetically distinct populations. Marine Ecology Progress Series. 408, 117-127.

Shone, R.W. and Booth, P.W.K. 2005. The Cape Basin, South Africa: A review. Journal of African Earth Sciences. 43, 196-210

Smita Achary, M., Satpathy, K.K., Panigrahi, S., Mohanty, A.K., Padhi, R.K., Biswas, S., Prabhu, R.K., Vijayalakshimi, S., Panigrahy, R.C. 2017. Concentration of heavy metals in the food chain components of the nearshore coastal waters of Kalpakkam, southeast coast of India. Food Control. 72, 232-243.

South Africa 1997. Foodstuffs, cosmetics and disinfectants act, 1972 (act no.54 of 1972)

Storelli, M.M., 2008. Potential human health risks from metals $(\mathrm{Hg}, \mathrm{Cd}$, and $\mathrm{Pb})$ and polychlorinated biphenyls (PCBs) via seafood consumption: Estimation of target hazard quotients (THQs) and toxic equivalents (TEQs). Food Chem. Toxicol. 46, 2782-2788.

Storelli, M.M., Garofalo, R., Giungato, D., Giacominelli-Stuffler, R., 2010. Intake of essential and non-essential elements from consumption of octopus, cuttlefish and squid. Food Addit. Contam. B 3, 14-18.

Tawfik, M. S. 2013. Metals content in the muscle and head of common fish and shrimp from Riyadh market and assessment of the daily intake. Pakistan Journal of Agricultural Sciences. $50,479-486$.

Tchounwou, P.B., Yedjou, C.G., Patlolla, A.K., Sutton, D.J., 2012. Heavy metal toxicity and the environment. Experientia supplementum. 101, 133-164

Teske, P. R., Golla, T.R., Sandoval-Castillo, J., Khoyi, A.E., van der Lingen, C.D., von der Heyden, S., Chiazzari, B., Jansen van Vuuren, B., Beheregaray, L.B. 2018. Mitochondrial DNA is unsuitable to test for isolation by distance. Science Report, 8, 8448

Trevizani, T. H., Petti, M. A. V., Ribeiro, A. P., Corbisier, T. N., Figueira, R. C. L. 2018. Heavy metal concentrations in the benthic trophic web of Martel Inlet, Admiralty Bay (King George Island, Antarctica). Marine Pollution Bulletin. 130, 198-205.

Tu, N.P.C., Ha, N.H., Matsuo, H., Tuyen, B.C., Tanabe, S., Takeuchi, I. 2012. Biomagnification profiles of trace elements through the food web of an integrated shrimp mangrove farm in $\mathrm{Ba}$ RiaVung Tau, South Vietnam, American Journal of Environmental Sciences. 8, 117-129.

USEPA (United States Environmental Protection Agency) 2007. Method 3051A: Microwave assisted acid digestion of sediment, sludges, soils and oils. Revision 1

van Aswegen, J.D., Nel, L., Strydom, N.A., Minnaar, K., Kylin H., Bouwman, H., 2019.

Comparing the metallic elemental compositions of Kelp Gull Larus dominicanus eggs and eggshells from the Swartkops Estuary, Port Elizabeth, South Africa. Chemosphere. 221, 533-542.

van der Lingen, C.D. 2002. Diet of the sardine Sardinops sagax in the southern Benguela 
upwelling system ecosystem. South African Journal of Marine Science 24, 301-306.

van der Lingen, C.D., Miller, T.W. 2011. Trophic dynamics of pelagic nekton in the Southern

Benguela Current ecosystem: Calibrating trophic models with stable isotope analysis. In:

Omori, K., Guo, X., Yoshie, N., Fujii, N., Handoh, I. C., Isobe, A., Tanabe, S. (Eds.).

Interdisciplinary Studies on Environmental Chemistry Vol. 5. Modelling and Analysis of

Marine Environmental Problems. TERRAPUB, Tokyo, 85-94.

van der Lingen, C.D., Weston, L.F., Sempa, N.N., Reed, C.C. 2015. Incorporating parasite data in population structure studies of South African sardine Sardinops sagax. Parasitology. 142, 156-167.

van der Vyver, J.S.F., Sauer, H.H.H., McKeown, N.J., Yemane, D., Shaw, P.W., Lipinski, M.R. 2015. Phenotypic divergence despite high gene flow for the chokka squid Loligio reynaudii: implications for fishery management. Journal of the Marine Biological Association of the UK. 96(7), 1507-1525.

Viera, C., Morais, S., Ramos, S., Delerue-Matos, C., Oliveira, M.B.P.P. 2011. Mercury, cadmium, lead and arsenic levels in three pelagic fish species form the Atlantic Ocean: Intraand inter-specific variability and human health risk for consumption. Food and Chemical Toxicology. 49, 923-932.

Wen,H., Carignan,J. 2007. Reviews on atmospheric selenium: Emissions, speciation and fate. Atmospheric Environment. 41, 7151-7165.

Wepener, V. and Degger, N. 2012. Status of marine pollution research in South Africa (1960present). Marine Pollution Bulletin. 64, 1508-1512.

Weston, L.F., Reed, C.C., Hendricks, M., Winker, H., van der Lingen, C.D. 2015. Stock discrimination of South African sardine (Sardinops sagax) using a digenean parasite biological tag. Fisheries Research. 164, 120-129.

WWF (World Wide Fund for Nature) 2014. From boat to plate: Linking the seafood consumer and supply chain Available at

http://awsassets.wwf.org.za/downloads/wwfsassi boattoplate web.pdf Date of access: 18 April 2019.

Wu, Q., Bouwman, H., Uren, R.C., van der Lingen, C. D., Vetter, W. 2019. Halogenated natural products and anthropogenic persistent organic pollutants in chokka squid (Loligo reynaudii) from three sites along the South Atlantic and Indian Ocean coasts of South Africa. Environmental Pollution. 255, 113282.

Yuan, Z., Luo, T., Liu, X., Hua, H., Zhuang, Y., Zhuang, X., Zhuang, L., Zhuang, Y., Wu, X., Ren, J. 2019. Tracing anthropogenic cadmium emissions: From sources to pollution. Science of the Total Environment. 676, 87-96.

\section{Further reading}

United States Environmental Protection Agency (USEPA), 1978. Metal accumulation in fishes and aquatic invertebrates: A literature review. Report EPA-600/3-78-103. 


\section{Table S1.}

Mean concentrations of metallic elements in sardine (SCS) and chokka (CCS) muscle tissue per site (mg/kg dry mass) with the detection limit of each element analysed. Elements not mentioned in text are presented for archival purposes.

\begin{tabular}{lllllllllllll}
\hline & \multicolumn{4}{c}{ SCS1 } & \multicolumn{2}{c}{ SCS2 } & \multicolumn{2}{c}{ CCS1 } & \multicolumn{2}{c}{ CCS2 } & \multicolumn{2}{c}{ CCS3 } \\
\hline & \multicolumn{1}{c}{ LOD } & Mean & \multicolumn{1}{c}{ SD } & Mean & SD & Mean & SD & Mean & SD & Mean & SD \\
\hline $\mathrm{B}$ & 0.0025 & 0.73 & 0.82 & 1.5 & 0.67 & 5.2 & 2.8 & 5.7 & 1.7 & 5.5 & 0.76 \\
$\mathrm{Mg}$ & 0.00003 & 1800 & 230 & 2100 & 220 & 3900 & 400 & 3400 & 270 & 3900 & 580 \\
$\mathrm{Al}$ & 0.0018 & 7.4 & 4.5 & 9.5 & 5.8 & 4.1 & 1.7 & 3.3 & 2.5 & 3.9 & 3.2 & \\
$\mathrm{P}$ & 0.00094 & 11000 & 1800 & 11000 & 1400 & 12000 & 600 & 1300 & 1400 & 12000 & 800 \\
$\mathrm{~K}$ & 0.0034 & 22000 & 2400 & 19000 & 2400 & 17000 & 1100 & 16000 & 1400 & 16000 & 900 \\
$\mathrm{Ti}$ & 0.000041 & 18 & 2.7 & 17 & 2.3 & 21 & 1.2 & 23 & 2.8 & 23 & 1.8 \\
$\mathrm{~V}$ & 0.000029 & 0.30 & 0.17 & 2.0 & 0.96 & 0.10 & 0.077 & 0.020 & 0.0042 & 0.048 & 0.031 \\
$\mathrm{Cr}$ & 0.00089 & 0.61 & 0.064 & 0.66 & 0.069 & 1.6 & 0.21 & 1.6 & 0.10 & 1.6 & 0.22 \\
$\mathrm{Mn}$ & 0.000016 & 2.2 & 1.0 & 2.3 & 0.93 & 2.6 & 1.3 & 1.0 & 0.19 & 1.0 & 0.15 \\
$\mathrm{Fe}$ & 0.0011 & 50 & 10 & 53 & 12 & 10 & 1.3 & 8.0 & 2.7 & 9.0 & 1.8 \\
$\mathrm{Co}$ & 0.000008 & 0.079 & 0.032 & 0.083 & 0.036 & 0.027 & 0.0060 & 0.013 & 0.0039 & 0.026 & 0.010 \\
$\mathrm{Cu}$ & 0.000012 & 3.5 & 0.68 & 3.2 & 0.41 & 20 & 8.9 & 21 & 7.9 & 15 & 3.2 \\
$\mathrm{Zn}$ & 0.000076 & 27 & 13 & 21 & 4.2 & 46 & 3.1 & 46 & 1.9 & 48 & 2.4 \\
$\mathrm{As}$ & 0.000012 & 2.7 & 0.55 & 4.1 & 0.95 & 17 & 6.1 & 13 & 2.1 & 17 & 2.1 \\
$\mathrm{Se}$ & 0.00011 & 1.2 & 0.17 & 1.6 & 0.28 & 2.8 & 0.63 & 2.8 & 0.53 & 2.7 & 0.25 \\
$\mathrm{Rb}$ & 0.0000023 & 3.6 & 0.26 & 3.1 & 0.25 & 11 & 0.82 & 8.0 & 0.76 & 9.0 & 1.4 \\
$\mathrm{Sr}$ & 0.0000056 & 5.0 & 2.8 & 5.7 & 1.7 & 15 & 2.5 & 11 & 2.1 & 13 & 1.6 \\
$\mathrm{Mo}$ & 0.0000023 & 0.056 & 0.025 & 0.49 & 0.22 & 5.2 & 2.8 & 5.7 & 1.7 & 5.4 & 0.76 \\
$\mathrm{Pd}$ & 0.00000098 & 0.010 & 0.015 & 0.0020 & 0.0024 & 0.011 & 0.0021 & 0.0079 & 0.0024 & 0.012 & 0.0066 \\
$\mathrm{Ag}$ & 0.0000098 & $<\mathrm{LOQ}$ & $<\mathrm{LOQ}$ & $<\mathrm{LOQ}$ & $<\mathrm{LOQ}$ & 0.40 & 0.34 & 0.65 & 0.32 & 0.41 & 0.15 \\
$\mathrm{Cd}$ & 0.000032 & 0.18 & 0.13 & 0.30 & 0.17 & 1.8 & 1.3 & 1.6 & 0.70 & 3.3 & 2.5 \\
$\mathrm{Sb}$ & 0.0000040 & 0.0040 & 0.0020 & 0.0048 & 0.0040 & 0.0090 & 0.0029 & 0.0062 & 0.0011 & 0.0068 & 0.0017 \\
$\mathrm{Ba}$ & 0.000021 & 0.42 & 0.19 & 0.68 & 0.25 & 0.16 & 0.052 & 0.014 & 0.024 & 0.17 & 0.063
\end{tabular}




\begin{tabular}{llllllllllll}
$\mathrm{Pt}$ & 0.0000062 & 0.0040 & 0.0042 & 0.0012 & 0.0017 & 0.011 & 0.0072 & 0.011 & 0.0056 & 0.0074 & 0.0052 \\
$\mathrm{Hg}$ & 0.0000085 & 0.0049 & 0.061 & 0.00057 & 0.0065 & 0.15 & 0.12 & 0.28 & 0.27 & 0.025 & 0.081 \\
$\mathrm{Tl}$ & 0.0000093 & 0.026 & 0.0065 & 0.11 & 0.022 & 0.21 & 0.044 & 0.17 & 0.036 & 0.21 & 0.086 \\
$\mathrm{~Pb}$ & 0.0000013 & 0.20 & 0.22 & 0.17 & 0.10 & 0.20 & 0.042 & 0.18 & 0.032 & 0.20 & 0.081 \\
$\mathrm{Th}$ & 0.0000023 & 0.0080 & 0.0098 & 0.0086 & 0.0067 & 0.0040 & 0.0011 & 0.0031 & 0.0012 & 0.0032 & 0.0014 \\
$\mathrm{U}$ & 0.0000011 & 0.0060 & 0.0054 & 0.0061 & 0.0033 & 0.0066 & 0.0041 & 0.0023 & 0.0019 & 0.0052 & 0.0017 \\
\hline
\end{tabular}

